\title{
Basaltic Dyke with Specific Volcanogenic Structures and Its Geomorphic Evolution: Unique Geoheritage of the Faroe Islands (North Atlantic Ocean)
}

\author{
Pavel Raška ${ }^{1} \cdot$ Richard Pokorný $^{2,3}$ (D) $\cdot$ Lukáš Krmíček $^{3,4,5} \cdot$ Simona Kuboušková $^{3} \cdot$ Lis Mortensen $^{6}$
}

Received: 4 May 2017 / Accepted: 15 March 2018 / Published online: 23 March 2018

(C) The European Association for Conservation of the Geological Heritage 2018

\begin{abstract}
Volcanic landforms resulting from Cenozoic volcanism represent the most peculiar features of global geodiversity and provide eminent narratives for geoeducation. Among them, however, relict volcanic forms and site-specific landforms in remote areas have received less attention. In this paper, we provide the first description of unique volcanogenic features (hereinafter referred to as pseudo-hieroglyphs) developed on a summit rock wall at the Sandfelli ridge near the village of Gjógv in the N Eysturoy Island (Faroe Islands). The geomorphic evolution of the ridge and rock wall during the Quaternary is described and detailed petrographic analyses of the volcanogenic features are provided. Based on observed petrographical features, we interpret the pseudohieroglyphs to probably represent unique examples of chaotic horizontal columnar jointing. Following the geomorphological and petrographic examination of the study site, we analyse current Faroese legislation aiming at nature conservation and use this case to discuss broader implications of geoheritage conservation and geotourism in distant regions.
\end{abstract}

Keywords Palaeogene volcanism $\cdot$ Geoheritage $\cdot$ Sandfelli dyke $\cdot$ Pseudo-hieroglyphs $\cdot$ Columnar jointing $\cdot$ Faroe Islands

\section{Introduction}

Rock outcrops produced by Cenozoic volcanism and later modified by other geomorphological agents represent one of the most peculiar features contributing to global geodiversity and providing representative narratives for geoeducation

Richard Pokorný

richard.pokorny@ujep.cz

1 Faculty of Science, Jan Evangelista Purkyně University, České mládeže 8, 40096 Ústí nad Labem, Czech Republic

2 Faculty of Environment, Jan Evangelista Purkyně University, Králova Výšina 3132/7, 40096 Ústí nad Labem, Czech Republic

3 Department of Geological Sciences, Faculty of Science, Masaryk University, Kotlářská 2, 61137 Brno, Czech Republic

4 Institute of Geology of the Czech Academy of Sciences, Rozvojová 269, 16502 Prague 6, Czech Republic

5 Faculty of Civil Engineering, AdMaS Centre, Brno University of Technology, Veveř́ 95, 60200 Brno, Czech Republic

6 Jarðfeingi, Faroese Geological Survey, Brekkutún 1, FO-188 Hoyvík, Faroe Islands aimed at the Earth crust dynamics (Erfurt-Cooper 2011; Németh et al. 2017). For this reason, opportunities and possibilities to combine effective conservation tools with the use of geoeducation potential of volcanic regions and landforms have been increasingly studied. In recent years (Erfurt-Cooper 2014; Moufti and Nemeth 2016), several extensive, as well as site-specific landforms, located mostly in active volcanic provinces, are being preserved under national and international legislation. Other sites are considered to be included in existing conservation programmes. Prominent active and dormant volcanic regions, covered by such programmes and/or legislation, include Volcanoes of Kamchatka (Russia), Hawaii Volcanoes National Park (USA), Jeju Volcanic Island and Lava Tubes (South Korea) or Surtsey Island (Iceland), which are all preserved under the UNESCO World Heritage Site scheme (http://whc.unesco.org/en/list).

Considerably less attention is paid to preservation and geoeducational utilization of non-active volcanic regions and to site-specific eroded volcanic landforms. Although some well-known sites have been preserved and presented to broad public for decades (e.g. Giant's Causeway in Ireland and Panská skála in the Czech Republic; Gilmore et al. 2007; Kubalíková 2016), many sites have only recently been 
suggested for conservation (e.g., Paluska et al. 2013), and introduced for geotourism and geoeducational purposes (see, e.g., Migoń \& Pijet-Migoń 2016 for SW Poland volcanic field; Irimus et al. 2015 for Harghita Mountains in Romania; Tefogoum et al. 2014 for Manengouba Volcano in Cameroon, and many others).

One such volcanic region, where diversity of site-specific volcanic features for geoeducation and geotourism purposes has not been studied in detail, is represented by the Faroe Islands (North Atlantic, Fig. 1). In addition, outcrops of volcanic rocks presented there have been significantly influenced by glaciation and subsequent modification by weathering and gravitational processes. This provides a valuable narrative for geoeducation to present geomorphic impact on exposure of volcanic landforms and on their further shaping.

With respect to conservation issues and geoeducation, Faroe Islands represent an example of remote sites of inactive volcanism, which may be assumed specific for three reasons: (i) these sites are poorly explored in terms of diversity of particular small-scale volcanic features, (ii) although some distant volcanic sites are protected within the international schemes (e.g. typically Protocol on Environmental Protection to the Antarctic Treaty 1991, in force since 1998), in other cases the conservation programmes have not yet evolved to an extent to such degree. At the same time- (iii) these sites increasingly draw attention of tourists because of growing global connectivity (e.g. Hall and Johnston 1995;
Maher 2007) and could be affected by both direct and indirect impacts of tourism.

During the systematic geological surveying of the Faroe Islands conducted during 2014-2016, we discovered unusual volcanogenic structures occurring on the surface of a basaltic dyke located in the northern part of the archipelago. To the recent knowledge, this is the only site with such structures within the whole Faroe Islands and no explicit reference to similar forms has been found elsewhere.

The paper presents the first detailed characterization of this volcanic feature (herein designated as pseudohieroglyphs; see further text) together with the analysis of its geomorphic evolution that resulted in its exposure and current morphology. Along, the research has raised further questions relevant for geoheritage conservation and its promotion for geotourism and geoeducation purposes. With the term geoheritage we herein refer to geological features shaped by geomorphological agents (cf. Reynard and Coratza 2007). The above-stated questions of geoheritage conservation addressed in this paper relate to balancing the conservation efforts of small-scale sites in remote areas, where direct conservation management is difficult, with possibilities for promotion of these sites for geoeducational purposes. Therefore, the aim of this study is to describe in details the observed pseudo-hieroglyphs and to investigate their formation and highlight them as unique geoheritage, which deserves preservation for the future.

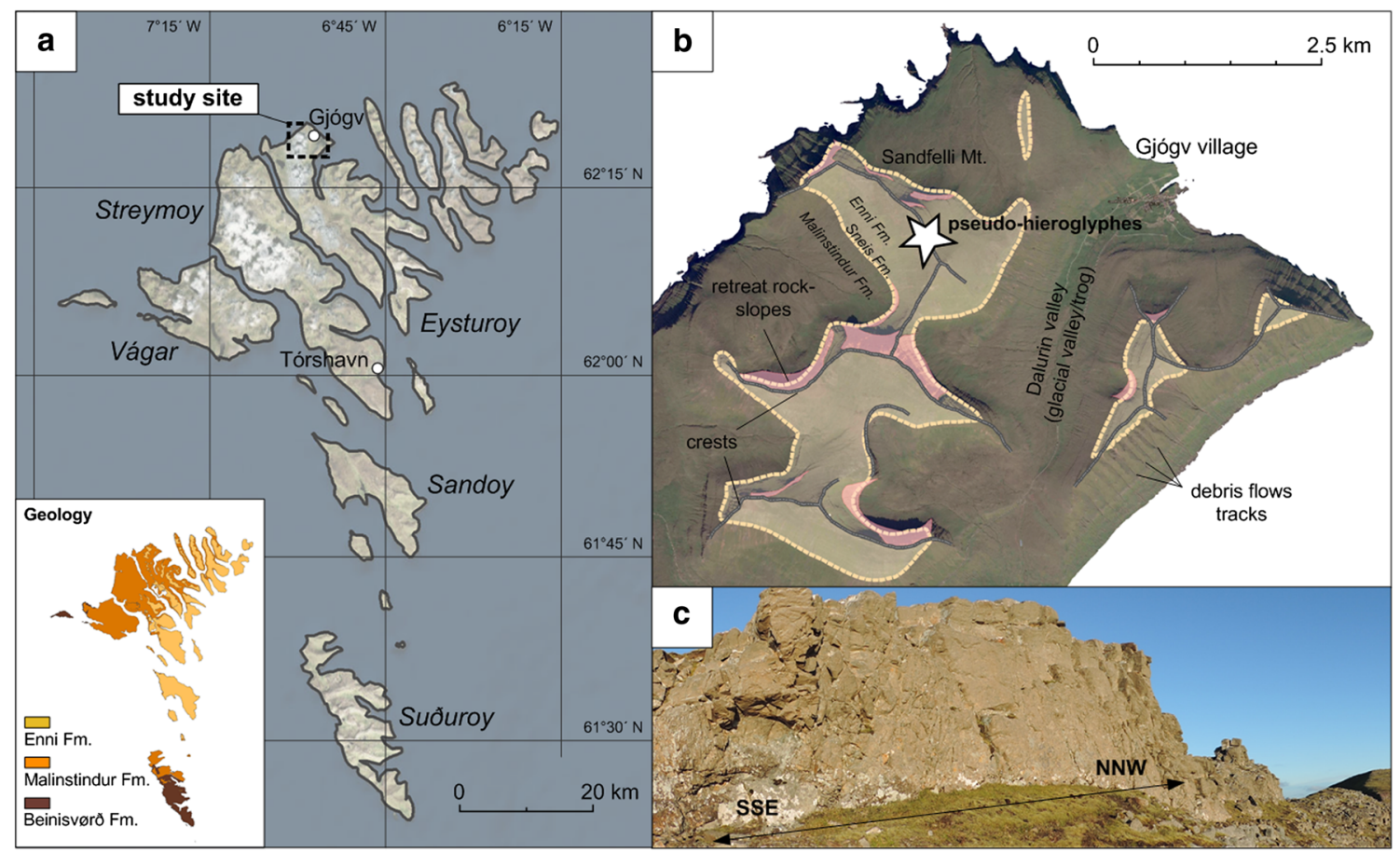

Fig. 1 a Location of the studied site within the Faroe Islands. b Main geomorphological features and stratigraphic setting of the Gjógv village surroundings. Note the position of crests and major retreat rock-slopes (pink colour) associated with the Sneis Formation (yellow dotted line) at the boundary between the Enni (youngest; light brown) and Malinstindur Formations (oldest; darker brown). c Studied site at the Sandfelli mountain ridge (photo: authors) 


\section{Geographical and Geological Setting}

The Faroe Islands (Føroyar) comprise an archipelago of 18 large islands and many smaller islets located in the North Atlantic Ocean (Fig. 1). Although the oldest settlement is documented as early as the 4th-6th centuries AD (Church et al. 2013), the archipelago is only sparsely populated due to its remoteness and harsh climate- 50,000 inhabitants live in this area of ca. $1400 \mathrm{~km}^{2}$. Approximately $40 \%$ of them live in the capital, Tórshavn, and the rest of the population lives in 120 smaller towns and villages (http://www.dst.dk). While being a part of the Kingdom of Denmark, the Faroe Islands have selfgovernment with their own parliament, Løgting, and a large degree of independence in government and legislation issues including a relation to nature conservation and tourism economy relevant for the scope of our research.

With respect to geology, the Faroe Islands were formed by a several kilometer thick series of subaerially emplaced plateau basalts and intercalated volcaniclastic strata of Palaeogene age ( 60-55 Ma; Schofield et al. 2017). The uppermost about $3 \mathrm{~km}$ of the stratigraphic column are exposed onshore while additional ca. $3^{1 / 2} \mathrm{~km}$ have been drilled in the Lopra-1/1 A well. The Faroe Islands Basalt Group has been divided into seven lithostratigraphic formations, namely, (from bottom to top): Lopra Fm., Beinisvørð Fm., Prestfjall Fm., Hvannhagi Fm., Malinstindur Fm., Sneis Fm. and Enni Fm (Passey and Jolley, 2009). The individual basaltic flows are often separated by volcaniclastic sediments (occasionally coal-bearing tuffitic claystone, sandstone or conglomerate of terrestrial origin) deposited between individual volcanic eruptions (Andersen et al. 2002; Waagstein et al. 2002; Passey and Jolley 2009; Pokorný et al. 2015; Kuboušková et al. 2016).

The volcanic strata and intercalated sediments have been penetrated by hundreds of basaltic intrusions. These sill and dyke intrusions were either contemporaneous with upper basaltic lava effusions or were intruded in response to a slight doming of the lava plateau during the termination of volcanic activity. Sills and dykes are generally comprised of picrites, olivine-phyric and plagioclase-phyric basalts of various thicknesses ranging between 1 and $20 \mathrm{~m}$. The most extensive intrusion found on the Faroe Islands is exposed over a length of $21 \mathrm{~km}$ (Rasmussen and Noe-Nygaard 1969; Rudberg 1984; Hald and Waagstein 1991).

The current terrain of the Faroe Islands is largely a result of the Quaternary glaciations (Jørgensen \& Rasmussen 1986) and by diverse weathering and gravitational processes during the Holocene. Therefore, glacial valleys, cirques, frontal and lateral moraines and subglacial erosional features are frequent phenomena, while many slopes have been later affected by rockfall, producing talus cones and blockfields, and by rockslides, landslides, solifluction and debris flows (see Humlum \& Christiansen 1998 for periglacial features).

\section{Results}

\section{Geomorphological Processes}

\section{Topographic Context}

The study site is located on the mountain of Sandfelli in the northernmost part of the Eysturoy Island, approximately $2.35 \mathrm{~km}$ WSW from Gjógv village (Fig. 1b). The major geomorphic feature in the region is a glacial valley, Dalurin, to the east of Sandfelli, stretching in a SW direction from the Gjógv village. Based on analyses of moraine systems, Humlum et al. (1996) assigned this valley to older glaciation stages in contrast to younger fresh-looking glacial cirques. Gjógv valley and two minor valleys in the west and south of the study area are drained by smaller water streams causing headward erosion and slope retreat of relic cirques. Individual basalt layers interlaid by volcaniclastic sediments are exposed on valley slopes, thus forming stepped slopes at some locations (e.g. NW margin of the area).

Valley slopes are currently modelled by solifluction and frequent debris flows; some of them are channelized debris flows (locally known as Áar-skriðulop; Dahl et al. 2012) with probable recurrence and strength to dissect the uppermost edge of the rock faces. The most distinct free faces and rock slopes closing the valleys and cirques are developed at the boundary between the Malinstindur and Enni Formations, which is represented by the relatively thin intervening Sneis Formation (Fig. 1b).

Crests between individual valleys are a result of frost action and slope retreat with possible role of lithologies with different intact strength. The most representative example is the studied rock wall-shaped summit frost-riven cliff (also summit tor sensu: Davies 1969; French 2007) located on the Sandfelli mountain ridge. It is the only locality described in the study area, where intrusion of the dyke into the less resistant rocks of the Enni Formation and subsequent frost weathering at the crest enabled the development of a 1-4 m high and ca. 100-m long rock wall (Fig. 1c).

\section{Pleistocene and Post-Glacial Evolution}

The evolution of this rock wall can be assigned to long-term weathering, most likely beginning in the Neogene and including Pleistocene as well as Holocene glaciations. The PreQuaternary landscape had a relatively low relief topography, which was transformed to high relief topography by glacial erosion during the Quaternary period. The glaciated landscape is characterised by deep valleys, narrow sounds and remaining high mountaintops. Jørgensen and Rasmussen (1986) mapped the upper limit of the Weichselian glaciation in the northern part of Eysturoy to about $600 \mathrm{~m}$ a.s.l. around Blámansfjall (ca $10 \mathrm{~km}$ to the South from the study site). Further north the upper limit of the glaciation was lower. Sandfelli with a summit $752 \mathrm{~m}$ a.s.l., is located northeast of Blámansfjall and would 
have had an upper glaciation limit less than $600 \mathrm{~m}$ a.s.l. This means that the summit of Sandfelli is a former nunatak representing an ice-free mountaintop during the last glaciation, with glaciers in the valleys below. For these reasons, the Sandfelli Mountain represents the remodelled remnants of the older, Pleistocene landscape.

The lower and upper time constraints for the major evolution of the Sandfelli mountain ridge can be derived only indirectly. During the Pleistocene, the non-glaciated ridge might have been subject to several phases of increased weathering activity, resulting in slope retreat and evolution of the arête form of the ridge. The current form of the studied rock wall seems to be a result of the thermal instabilities during the late Weichselian glaciation and the succeeding post-glacial period (i.e. paraglacial instability). Possible effects of sub-surface weathering on the non-glaciated ridge during the Weichselian glaciation that would imply evolution of two-cycle tors (Davies 1969) seems rather irrelevant in this climatic region (cf. Embleton and King 1975).

During the post-glacial period, the Sandfelli has been subject to frost shattering, cryogenic weathering and solifluction (gelifluction) of the weathered material downslope. Timing of deglaciation and glacial retreat in the Faroe Islands, that would indicate increased thermal variability and weathering, is still a subject of research (Jørgensen and Rasmussen 1986; Humlum et al. 1996; Olsen et al. 2010; Jessen et al. 2008).

The decrease in periglacial activity on the Faroe Islands is assigned to mid-Holocene ( 8500 to $3000 \mathrm{cal}$. year BP) based on radiocarbon dating of various landforms by Humlum and Christiansen (1998). The rock wall has been subject to mild periglacial climate with high humidity in close proximity to open ocean (i.e. high air salinity) during early to midHolocene, which may have caused the weathered rounded shape of basalt blocks. On the other hand, Jessen et al. (2008) document a cooling period after $7.410 \mathrm{cal}$. year BP and further cooling after 4.190 cal. year BP with freeze/thaw sequences affecting the weathering rates. Notably, high spatial variability in time constraints to periglacial processes due to microclimate diversity (André 2003) must be generally taken into account.

\section{Geological Setting}

The studied intrusion/rock wall is located on the crest of the Sandfelli mountain ridge (752 $\mathrm{m}$ a. s. 1.). The mountainside is comprised by brown-grey aphyric to olivine-phyric basalts of the Malinstindur Fm. They are overlain by brown, flow-banded aphyric to olivine-phyric tabular basalts of the Sneis Fm., with the eroded and weathered boundary situated around $550 \mathrm{~m}$ above sea level. This boundary is termed the "C-horizon" in older literature (Rasmussen and Noe-Nygaard 1969). Another erosion boundary separating the youngest stratigraphic member of grey, weakly amygdaloidal aphyric to plagioclase-phyric basalts belonging to the Enni Fm. from the underlying Sneis Fm. is located approximately $30 \mathrm{~m}$ higher and forms the uppermost part of the Sandfelli crest (Passey and Jolley 2009).

\section{Pseudo-Hieroglyphs_Definition, Morphology, Petrography and Origin}

The spectacularly exposed NNW-SSE trending dyke of greyblack compact basalt without macroscopically noticeable mineralization forms the elongated top of the Sandfelli mountain ridge (Fig. 2; GPS are $62^{\circ} 19^{\prime} 21.2^{\prime \prime} \mathrm{N}, 6^{\circ} 59^{\prime} 30.3^{\prime \prime} \mathrm{W}$ to $62^{\circ}$ $19^{\prime} 19.8^{\prime \prime} \mathrm{N}, 6^{\circ} 59^{\prime} 28.6^{\prime \prime} \mathrm{W}$ ). Its orientation is nearly perpendicular to the regionally predominant fault system in the northern part of the archipelago (Passey and Jolley 2009). The dyke has been dissected by frost weathering and subsequent erosion into the striking shape of summit frost-riven tors and cliffs (cf. French 2007; Gutiérrez 2005).

The west-oriented side of the rock wall is covered by dense mosaic of angular to rounded polygonal convex structures of
Fig. 2 The NNW-SSE trending dyke exposed on top of the Sandfelli mountain ridge (photo: authors)

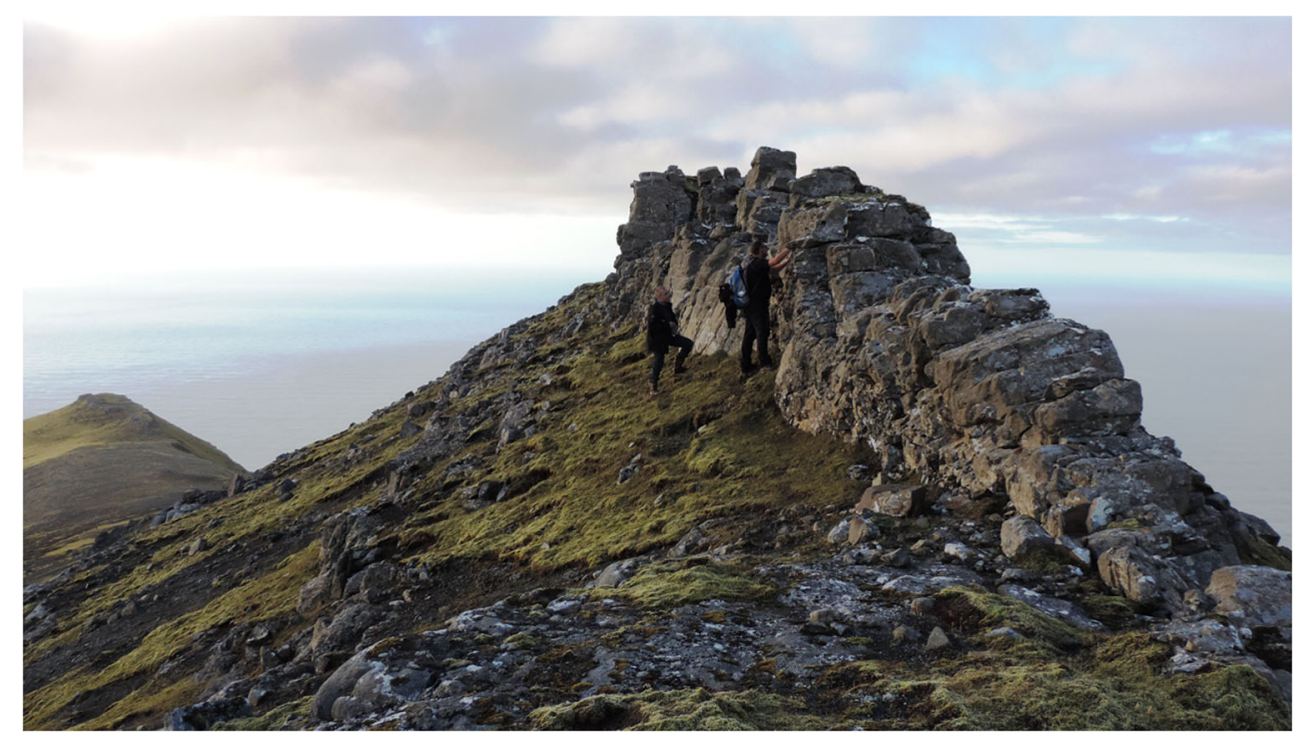


Fig. 3 Macroscopic character of the rock wall of the Sandfelli dyke with dense mosaic of angular to rounded polygonal convex structures-pseudo-hieroglyphs. Here, we propose subsequent timing necessary for their formation: observed features were created due to the (i) subaerial intrusion of thinner dyke into massive lava and (ii) its rapid cooling. Relatively high cooling rate across the thin intrusion resulted (iii) in "freezing" of initial stage of columnar jointing represented by chaotic structures on the dyke wall (photo: authors)

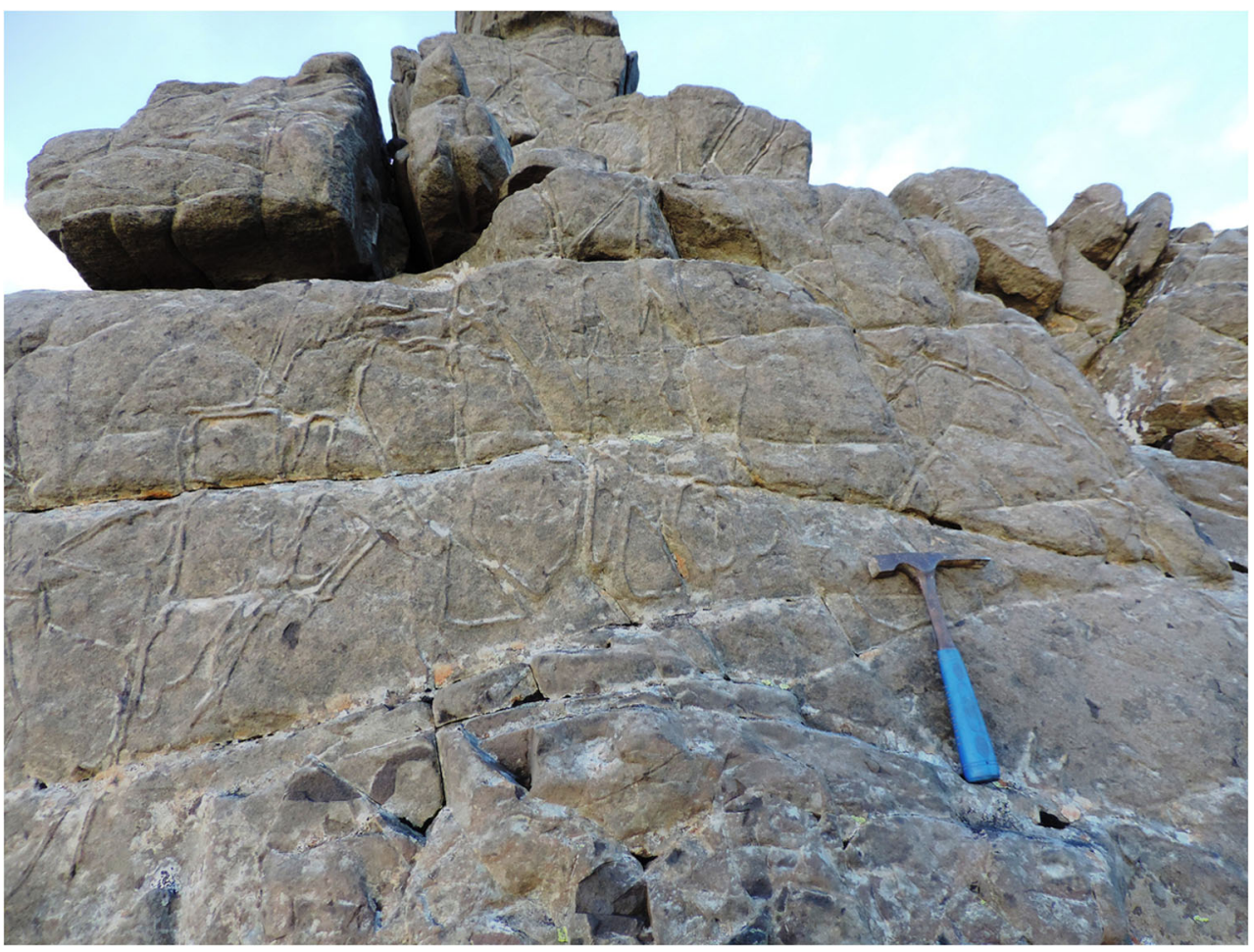

single- or more often double-row lines (Figs. 3 and 4) designated as pseudo-hieroglyphs. The term is inferred from the following definition: "Hieroglyph is any sort of sedimentary mark or structure occurring on a bedding plane." (Geller et al. 2003, p. 164). The prefix "pseudo-" expresses that the observed hieroglyphs are neither developed in a sedimentary rock, nor represent surface features of a bedding plane. Here, we loosely apply the term pseudo-hieroglyph to a surface textural feature mark rectangular pattern on a flat surface of a rock. The height of individual pseudo-hieroglyphs of triangular or semicircular cross-section generally reaches up to $5 \mathrm{~mm}$. No similar structures were observed on the opposite east-oriented side of the rock wall.

According to our petrographical observations, the Sandfelli dyke is composed of fine-grained, occasionally weakly
Fig. 4 A close-up view on pseudo-hieroglyphs. a Characteristic shape of rounded polygonal convex structure highlighted by red colour; b Dense mosaic of irregular pseudo-hieroglyphs. c Pseudo-hieroglyphs with doublerow lines (photo: authors)
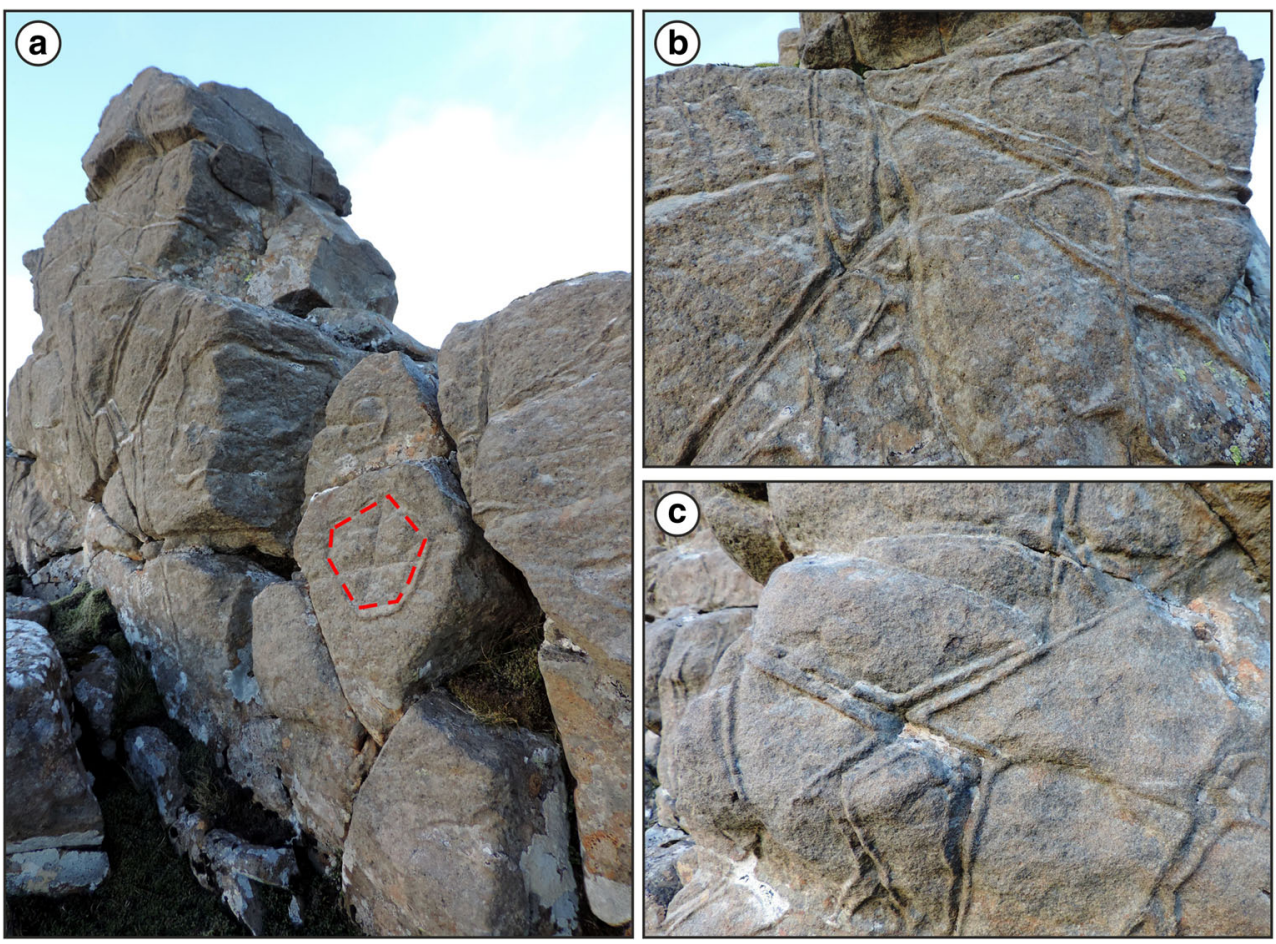
feldspar-phyric, tholeiitic basalt characterised by hyaloophitic texture, i.e., it consists of plagioclase laths ( $<1 \mathrm{~mm}$ in length) which are enclosed in a mixture of anhedral clinopyroxene and altered basaltic glass - tachylyte (Fig. 5a, b). Relatively uniform distribution of interstitial tachylyte is indicative of rapid cooling during the dyke emplacement without dramatic changing of P-T-X conditions (e.g. Kuboušková et al. 2016; Ulrych et al. 2017). Petrographic thin sections made from marginal pseudo-hieroglyphs revealed that they do not texturally or compositionally deviate from the host basaltic rock (Fig. 5c, d). The only difference is that feldspars in pseudo-hieroglyphs can be variably affected by weathering (Figs. 5e, f).

By the general view to the rock wall, it is possible to observe a basic arrangement of the pseudo-hieroglyphs, which copy the jointing surfaces of the supposed initial horizontal columns, which were generated by the cooling contraction subsequent to the intrusion of the basaltic magma. However, the mosaic is significantly denser in many places, alternatively occurs in the centre of the column surface. Based on observed petrographical features, the pseudo-hieroglyphs may represent unique examples of "frozen" chaotic stage of horizontal columnar jointing where observed dense mosaic of polygonal convex structures of various shapes predisposes future columns. The columnar jointing is a typical feature of basaltic rocks and it was described in detail by Spry (1962) and more recently by Hetényi et al. (2012). Considering the relatively rapid cooling of the dyke deduced from presence of basaltic glass in the rock groundmass along the rock wall, the columnar jointing did not have sufficient time to develop perfectly; however, the processes leading to the formation of such a volcanogenic structure can be more complex with a number of internal and external factors (see Long and Wood 1986; Philips et al. 2013 and references therein).

\section{Discussion}

Following the aims of this paper, two major questions arise regarding the potential of the study site and present
Fig. 5 Photomicrographs of the Sandfelli dyke. a Characteristic hyaloophitic texture consisting from plagioclase laths sitting in a mixture of anhedral clinopyroxene and altered basaltic glass (parallel polars). b Crossed polar view of the same image. c Textural development of pseudohieroglyphs (above the dashed red line) in cross-section (parallel polars). d Crossed polar view of the same image. e A close-up view on pseudo-hieroglyph rim affected by weathering. $\mathbf{f}$ Crossed polar view of the same image. Cpx, clinopyroxene; $\mathrm{Pl}$, plagioclase
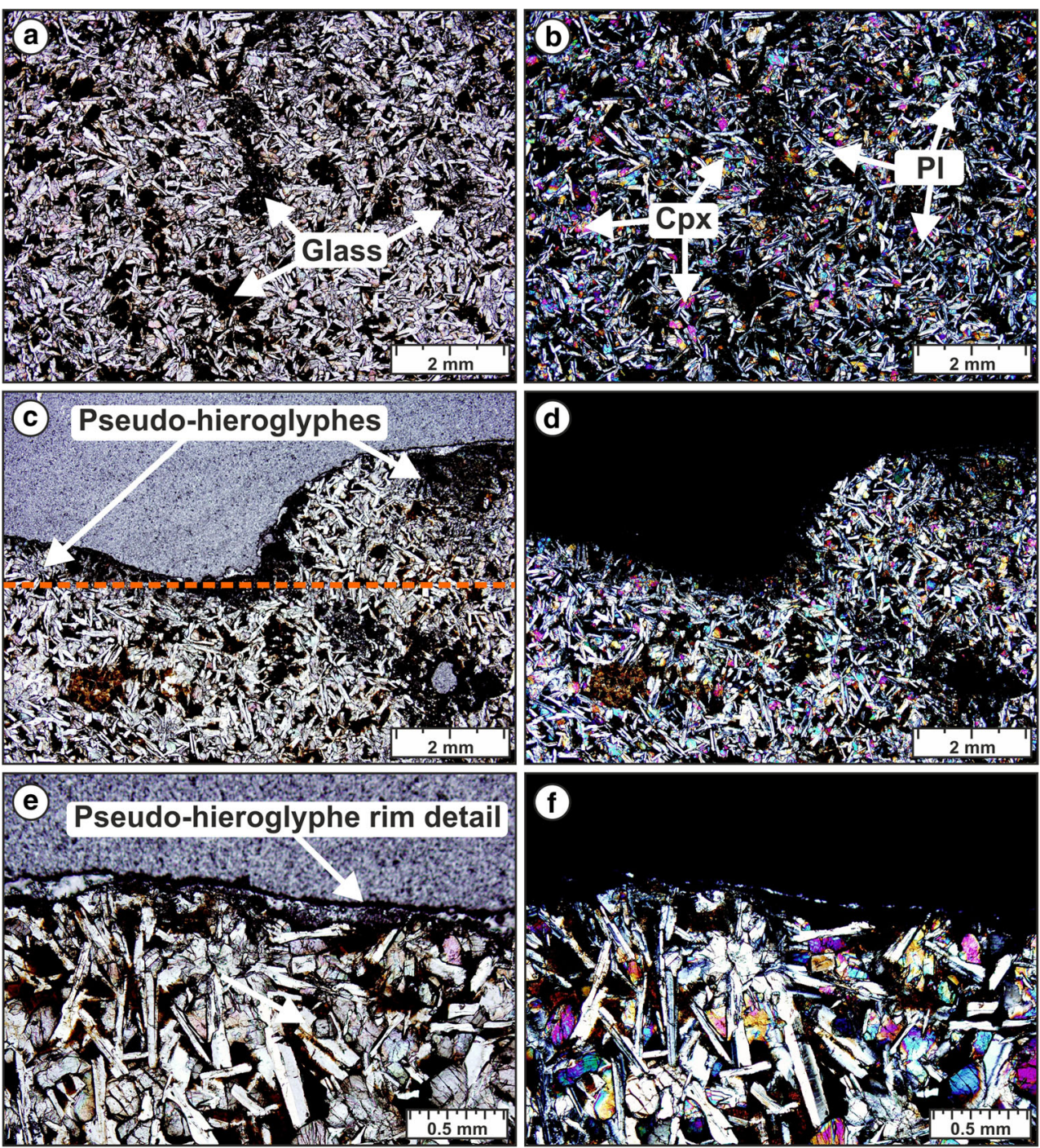
petrographical features as a geoheritage and subject for geoeducation. First, the geological and geomorphological uniqueness of the site must be addressed and, second, the possibilities for finding the optimal mode of its promotion as a tourism destination should be considered (economic benefit sensu Pralong 2005 is not explicitly addressed here). In this respect, the study site may provide a useful case study for similar cases in distant regions.

\section{Uniqueness of the Study Site}

The geological and geomorphological uniqueness of the study site was evaluated based on thorough review of scholarly writing as well as tourist guides. Since the size of the study site is small (approx. $200 \mathrm{~m}^{2}$ ), the legitimacy of its promotion must be evident. Compared with other protected sites in remote areas with large exposed dyke systems such as those in the Hopi Buttes in USA (e.g. Muirhead et al. 2016; Re et al. 2015), Sandfelli dyke with unique surface volcanogenic structures deserve protection on its own scale. Regarding its geomorphological significance, it must be noted that summit tors or summit frost-riven cliffs in form of rock walls represent frequent landform in formerly glaciated (paraglacial) and periglacial areas worldwide (Demek 1964; Embleton and King 1975; Gutiérrez 2005). Therefore, extrinsic geodiversity value of the study site is rather low in the context of glacial aspects. On the other hand, the study site represents the only described example in the Faroe Islands, resulting from specific local conditions of basalt-into-basalt intrusion; thus it may be considered as having significant intrinsic geodiversity value within the geological complexity of the archipelago (cf. Reynard and Panizza 2005).

Regarding the petrographical uniqueness of the site, no other examples of the described pseudo-hieroglyphs have been found in the literature. While the volcanic intrusions into other lithologies are known (e.g. the Great Devil's Wall melilitite dyke intrusion into sandstone in the Czech Republic, Fig. 6a, Ulrych et al. 2014; Vrkoč basalt dyke intrusion in sandstones in the Czech Republic, Fig. $6 \mathrm{~b}$, Raška and Cajz 2016; diabase intrusion into gneiss in the Nain area of Labrador; dykes connected to diatreme systems in Hopi Buttes volcanic field in USA, Muirhead et al. 2016), there are only few described examples of intrusions into the similar lithologies, excavated by erosional processes into the long, vertical rock walls (for terminology see section 1; e.g. the České středohoří Mts. in the Czech Republic or the Disko Island in Greenland, Coufalík et al. 2015, or the Ruapehu volcano, New Zealand, Fig. 6c-e). At the same time, such lithology seems to be the major factor affecting
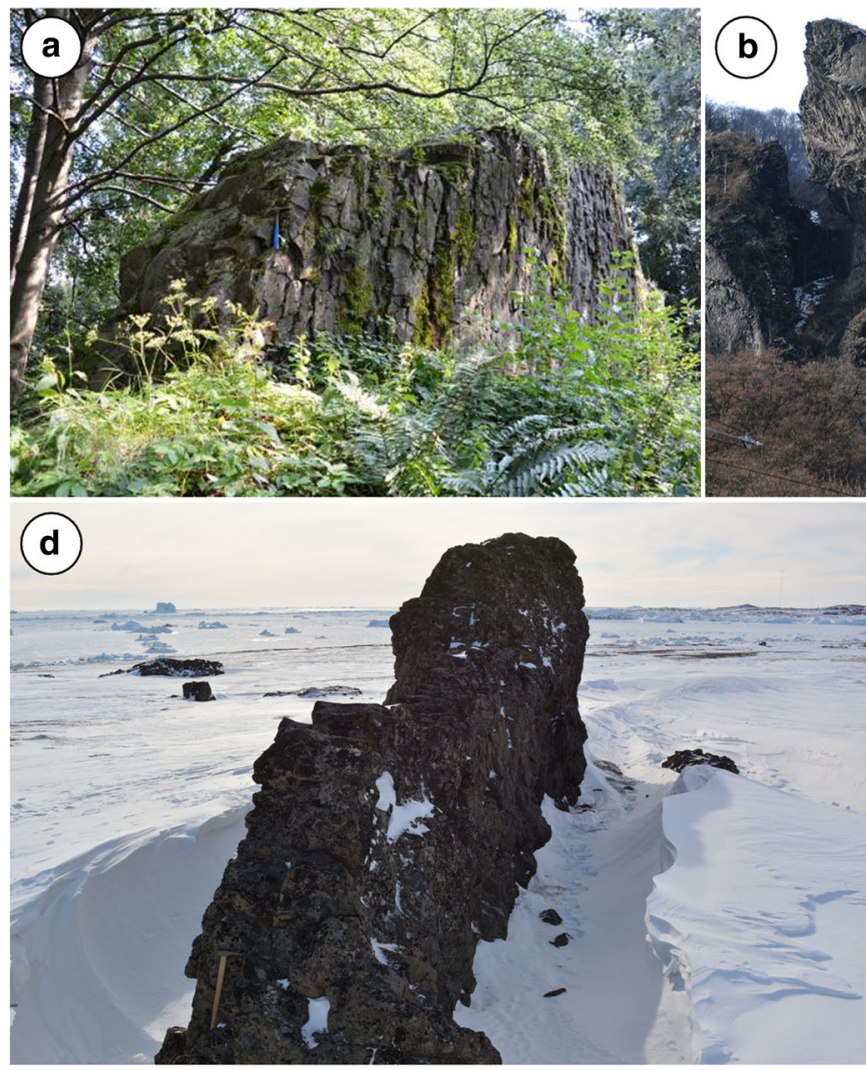

Fig. 6 Example of classical geoheritage localities with exposed dyke wall. a The Great Devil's Wall melilitite dyke (site 30 in Ulrych et al. 2014) and b Vrkoč basalt dyke in sandstones in Czech Republic. Examples of basalt-into-basalt or similar-like intrusions: $\mathbf{c}$ Čertova jizba
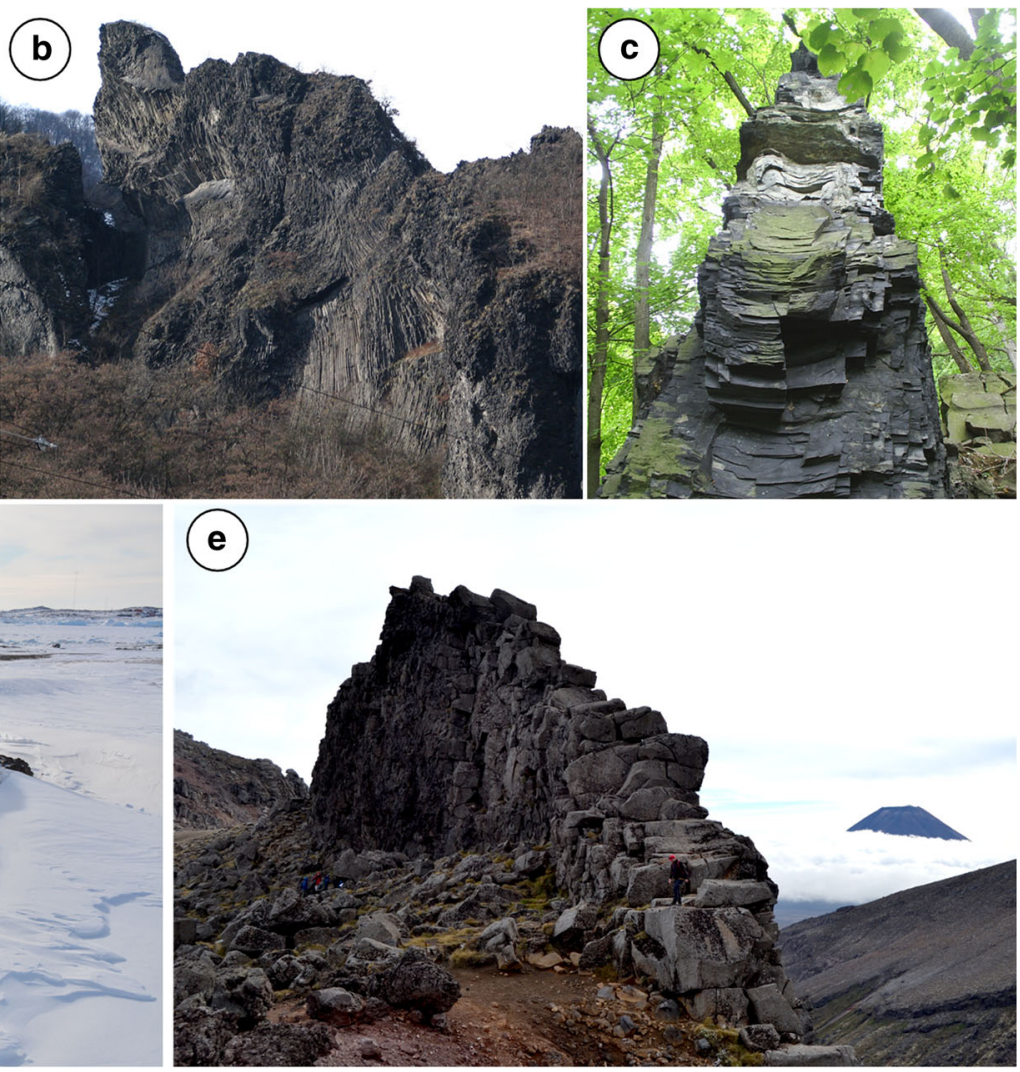

(Devil's room) in the Czech Republic, d dyke on the Disko Island in Greenland (site DIK01 in Coufalík et al. 2015) and e polygonally jointed, andesitic dyke on Ruapehu volcano, North Island, New Zealand (photos a-d: authors, e Uni Árting) 
the rock behaviour during cooling and resulting in the formation of pseudo-hieroglyphs. Nevertheless, even the similar lithological setting at other sites usually produce typical columnar disintegration, which is the most prominent feature, preserved in volcanic sites; thus, to our current knowledge, the described site with pseudo-hieroglyphs represents the first of its kind documented worldwide.

\section{Geotourism and Its Limits}

The second issue that must be considered is the possibility to balance promotion and preservation dimension of the study site. Although distant regions and subarctic islands and archipelagos in particular still cannot compare with other regions in terms of tourism frequency, their attractiveness is gradually increasing; because of better transportation, connection as well as the tourists' desire for the unknown (cf. Baldacchino 2015). In 2015, for instance, record numbers of tourists have been monitored in the Faroe Island with more than 40,000 passengers in the local Vágar airport (http://icelandmonitor. mbl.is) and overall number of tourists increased from ca. 50,000 in 1975 to ca. 300,000 in 2016 (Statistics Faroe Islands 2016). The tourist frequency may certainly contribute to regional environmental change and should raise new concerns about nature conservation.

Currently, the main nature conservation is governed by legislation (Faroese Løgting Act Nr. 110 from 29. June 1995; Law Nr. 1101995 in references). According to this act, all nature areas outside towns and villages are conserved and all construction work needs permission. Some nature areas have been specifically declared for conservation according to this law, including the Leynavatn area (Streymoy) and Mølheyggjar (Sandoy). Further nature conservation is covered by additional legislation. One example is the town planning act, Faroese Løgting Act Nr. 19 from 18 March 2013 (Law Nr. 19 2013), which allows towns to declare conserved nature areas within the town areas. Another example is the Faroese Løgting Act Nr. 53 from 27. November 1952 about plantations (Law Nr. 53 1952). According to the plantation law, a number of areas have been declared for nature conservation for tree planting in all regions of the Faroe Islands.

Currently, no conservation area in the Faroe Islands is declared according to IUCN classification, although initiatives have been taken to update nature conservation mechanisms and to establish a national park (Koltur Island). The islands of Mykines, Nólsoy and Skúgvoy were included into the system of "Wetlands of International Importance" within the Ramsar Treaty in 2012 (Joensen 2001, Petersen 2015, http://ramsar. org, http://us.fo).

Summarizing current efficacy of legal nature conservation in the Faroe Islands, the following example may be used to illustrate current benefits and limits. Existing legislation in the Faroe Islands has explicit rules about traffic in the nature, but it has difficulties regulating modern nature tourism. One example is the situation at Mykines which has experienced problems caused by fast growing numbers of visitors, since the islet of Mykineshólmur was included within the Ramsar Treaty in 2012 (Ramsar Committee for Mykines 2016). Possible threats from non-regulated tourist movement include not only disturbance of tourist paths exceeding loading capacity, but also trampling new paths resulting in biodiversity degradation and sheet erosion (Grabherr 1982; Cole 2004), degrading geological and geomorphological sites by collecting samples, or vandalism such as scratching or even painting (Buckley and Pannell 1990; Newsome et al. 2012). The Faroese government is therefore planning new legislation on nature conservation with a view to more efficiently controlling the movement of users of the nature areas (Faroese Government 2015). In addition, the necessity for local-based or community-based tourism and nature conservation management is evident (cf. Ceballos-Lascurain 1996; Slavíková et al. 2017) in remote and sparsely populated tourist destinations such as the Faroe Islands.

\section{Conclusions}

In this study, we used geological and geomorphological mapping and laboratory petrographical analyses to introduce the first detailed description of volcanogenic features referred to as pseudo-hieroglyphs as developed at a summit rock wall on the Sandfelli mountain ridge on the island of Eysturoy (Faroe Islands). The geomorphic evolution of the site, which represents a former nunatak during the Weichselian glaciation, was long lasting, but the increasing rates of rock disintegration and weathering dates back to thermal instabilities in the late Weichselian and beginning of the Holocene. Geologically, the site represents a unique example of basalt-to-basalt intrusion, which enabled the formation of volcanogenic features interpreted as "frozen" chaotic stage of horizontal columnar jointing. Furthermore, the study site was used as a representative example to discuss issues related to balancing geoheritage conservation and geotourism in distant regions, such as Faroe Island. In particular, we showed that despite of legislation efforts, increasing geotourism on attractive sites may result in threats to nature conservation and raise the necessity for further research and policy actions.

Acknowledgements We sincerely thank Bjartur Brekkstein (Velbastaður, Streymoy, FO) for an introduction to the locality and to Uni E. Árting (Fróðskaparsetur Føroya - University of the Faroe Islands and Jarðfeingi - The Faroese Geological Survey) for the administrative help during the geological surveying on the Faroe Islands and for providing the photo on Fig. 6e. Last but not least, we also thank Martin V. Heinesen (Jarðfeingi) for the helpful advice in Faroese geomorphology and also the English grammar and text-flow improvement. We also acknowledge the editor-inchief (Kevin Page) for a great willingness in technical editing of the manuscript and the reviewers for the highly valuable advice and recommendations. 
Funding Information Our field research was financially supported by the projects OPVK (Operational Program - Education for Competitiveness) EnviMod (CZ.1.07/2.2.00/28.0205), IGA UJEP 1/2014 and PEGASTFA (UJEP-SGS-2017-44-004-3). The work of Lukáš Krmíček was covered by the BUT project LO1408 "AdMaS UP - Advanced Materials, Structures and Technologies", supported by the Ministry of Education, Youth and Sports under the "National Sustainability Programme I" as well as by the institutional project RVO 67985831 of the Institute of Geology of the CAS.

\section{References}

Andersen MS, Sørensen AB, Boldreel LO, Nielsen T (2002) Cenozoic evolution of the Faroe platform: comparing denudation and deposition. In: Doré AG, Cartwright JA, Stoker MS, Turner JP, White N (eds) Exhumation of the North Atlantic margin: timing, Mechanisms and implications for petroleum exploration. Geol Soc London Spec Publ 196:291-311. https://doi.org/10.1144/GSL.SP.2002.196.01.16

André MF (2003) Do periglacial landscapes evolve under periglacial conditions? Geomorphology 52:149-164. https://doi.org/10.1016/ S0169-555X(02)00255-6

Baldacchino B (ed) (2015) Archipelago tourism: policies and practices. Routledge, London

Buckley RC, Pannell J (1990) Environmental impacts of tourism and recreation in national park and conservation reserves. J Tour Stud $1: 24-32$

Ceballos-Lascurain H (1996) Tourism, ecotourism, and protected areas: the state of nature-based tourism around the world and guidelines for its development. IUCN, Cambridge

Church MJ, Arge SV, Edwards KJ, Ascough PL, Bond JM, Cook GT, Dockrill SJ, Dugmore AJ, McGovern TH, Nesbitt C, Simpson IA (2013) The Vikings were not the first colonizers of the Faroe Islands. Quat Sci Rev 77:228-232. https://doi.org/10.1016/j.quascirev.2013. 06.011

Cole DN (2004) Impacts of hiking and camping on soils and vegetation: a review. In: Buckley R (ed) Environmental impacts of ecotourism. CABI, Wallingford, pp 41-60. https://doi.org/10.1079/ 9780851998107.0041

Coufalík P, Zvěřina O, Krmíček L, Pokorný R, Komárek J (2015) Ultratrace analysis of $\mathrm{Hg}$ in alkaline lavas and regolith from James Ross Island. Antarct Sci 27:281-290. https://doi.org/10.1017/ S0954102014000819

Dahl M-PJ, Mortensen LE, Jensen NH, Veihe A, de Neergaard M (2012) Classification of debris flow phenomena in the Faroe Islands. Geogr Tidsskr-Den 112:27-39. https://doi.org/10.1080/00167223.2012. 707804

Davies JL (1969) Landforms of cold climates. MIT Press, London

Demek J (1964) Castle koppies and tors in the Bohemian Highland (Czechoslovakia). Biul Peryglac 14:195-216

Embleton C, King CAM (1975) Periglacial geomorphology. Edward Arnold, London

Erfurt-Cooper P (2011) Geotourism in volcanic and geothermal environments: playing with fire? Geoheritage 3:187-193. https://doi.org/10. 1007/s12371-010-0025-6

Erfurt-Cooper P (ed) (2014) Volcanic tourist destinations. Springer, New York

Faroese Government (2015) Mál at fremja. Fylgiskjal til samgonguskjalið millum Javnaðarflokkin, Tjóðveldi og Framsókn 14. september 2015. (Translated: coalition co-operation document signed by representatives of the government parties, Javnaðarflokkur, Tjóðveldi and Framsókn, September 14th 2015). Available at <http://cdn.lms. fo/media/6803/fylgiskjal-mal-at-fremja-kvf.pdf>

French HM (2007) The periglacial environment. Wiley, Chichester
Geller E (ed) et al (2003) Dictionary of earth science, 2nd edn. McGrawHill, New York

Gilmore A, Carson D, Ascenção M (2007) Sustainable tourism marketing at a world heritage site. J Strategic Market 15:253-264

Grabherr G (1982) The impact of trampling by tourists on a high altitudinal grassland in the Tyrolean Alps, Austria. Vegetatio 48:209-217. https://doi.org/10.1007/BF00055262

Gutiérrez M (2005) Climatic geomorphology. Elsevier, Amsterdam

Hald N, Waagstein R (1991) The dykes and sills of the early tertiary Faeroe Island basalt plateau. Trans R Soc Edinb Earth Sci 82:373388. https://doi.org/10.1017/S0263593300004211

Hall CM, Johnston ME (1995) Polar tourism: tourism in the Arctic and Antarctic regions. Wiley, Chichester

Hetényi G, Taisne B, Garel F, Médard É, Bosshard S, Mattsson HB (2012) Scales of columnar jointing in igneous rocks: field measurements and controlling factors. Bull Volcanol 74:457-482. https:// doi.org/10.1007/s00445-011-0534-4

http://icelandmonitor.mbl.is (2015) Record number of visitors to the Faroe Islands. 10 Aug 2015 Accessed 06 Feb 2017

http://ramsar.org (2012) The Faroe Islands (Denmark) designates three islands in the Faroes. 10 June 2012 Accessed 27 Feb 2017

http://us.fo (2015) RAMSAR - Implementering på Færøerne .17 Nov 2015 Accessed 27 Feb 2017

http://whc.unesco.org/en/list (2017) UNESCO World Heritage List. Accessed 6 Oct 2017

http://www.dst.dk (2017) Denmark Statistical Office. Accessed 6 Oct 2017

Humlum O, Christiansen HH (1998) Mountain climate and periglacial phenomena in the Faeroe Islands. Permafrost Periglac 9:189-211. https://doi.org/10.1002/(SICI)1099-1530(199807/09)9:3<189:: AID-PPP287>3.0.CO;2-N

Humlum O, Christiansen HH, Svensson H, Mortensen LE (1996) Moraine Systems in the Faroe Islands: glaciological and climatological implications. Geogr Tidsskr 96:21-31. https://doi.org/10.1080/ 00167223.1996 .10649373

Irimus IA, Balint-Balint L, Dombay S, Crisan H, Magyari-Saska Z (2015) Classification and evaluation criteria for volcanic geomorphosites in Harghita Mountains. In: Science and technologies in geology, exploration and mining, SGEM, Vol. I, Book Series: International Multidisciplinary Scientific GeoConference-SGEM, pp 77-84. https://doi.org/10.5593/SGEM2015/B11/S1.010

Jessen CA, Rundgren M, Björck S, Andresen CS, Conley DJ (2008) Variability and seasonality of North Atlantic climate during the early Holocene: evidence from Faroe Island lake sediments. The Holocene 18:851-860. https://doi.org/10.1177/0959683608093521

Joensen JP (ed) (2001) Frágreiðing frá arbeiðsbólki viðvíkjandi Náttúru\& Umhvørvisvernd. Nr. 603-200100336-2. Report from working group on nature and environmental conservation in the Faroe Islands. Oljumálastýrið, Tórshavn

Jørgensen G, Rasmussen J (1986) Glacial Striae, roches moutonnées and ice movements in the Faroe Islands. Geological survey of Denmark, DGU series C, N0.7, Copenhagen

Kubalíková L (2016) Geomorphological heritage and geoconservation in the Czech Republic. In: Pánek T, Hradecký J (eds) (2016) Landscapes and landforms of the Czech Republic. Springer Verlag, Berlin-Heidelberg, pp. 387-398

Kuboušková S, Krmíček L, Coufalík P, Pokorný R (2016) Petrological and geochemical characteristics of Palaeogene low-rank coal on the Faroe Islands: restricted effects of alteration by basaltic lava flows. Int J Coal Geol 165:157-172. https://doi.org/10.1016/j.coal.2016. 08.009

Long PE, Wood BJ (1986) Structures, textures, and cooling histories of Columbia River basalt flows. Geol Soc Am Bull 97:1144-1155. https://doi.org/10.1130/0016-7606(1986)97<1144:STACHO>2.0. $\mathrm{CO} ; 2$ 
Maher PT (2007) Arctic tourism: a complex system of visitors, communities, and environments. Polar Geogr 30:1-5. https://doi.org/10. 1080/10889370701666507

Migoń P, Pijet-Migoń E (2016) Overlooked geomorphological component of volcanic Geoheritage-diversity and perspectives for tourism industry, Pogórze Kaczawskie region, SW Poland. Geoheritage 8: 333-350. https://doi.org/10.1007/s12371-015-0166-8

Moufti MR, Nemeth K (2016) Geoheritage of volcanic Harrats in Saudi Arabia. In: Eder W, Bobrowsky PT, Martínez-Frías J (eds) Geoheritage, Geoparks and Geotourism. Springer, Heidelberg, pp 1-194. https://doi.org/10.1007/978-3-319-33015-0

Muirhead JD, Van Eaton AR, Re G, White JD, Ort MH (2016) Monogenetic volcanoes fed by interconnected dikes and sills in the Hopi Buttes volcanic field, Navajo Nation, USA. B Volcanol 78:11. https://doi.org/10.1007/s00445-016-1005-8

Németh K, Casadevall T, Moufti MR, Marti J (2017) Volcanic Geoheritage. Geoheritage 9:251-254. https://doi.org/10.1007/ s12371-017-0257-9

Newsome D, Dowling R, Leung Y-F (2012) The nature and management of geotourism: a case study of two established iconic geotourism destinations. Tourism Manage Persp 2-3:19-27. https://doi.org/10. 1016/j.tmp.2011.12.009

Olsen J, Björck S, Leng MJ, Gudmundsdóttir ER, Odgaard BV, Lutz CM, Kendrick CP, Andersen TJ, Seidenkrantz M-S (2010) Lacustrine evidence of Holocene environmental change from three Faroese lakes: a multiproxy XRF and stable isotope study. Quat Sci Rev 29:2764-2780. https://doi.org/10.1016/j.quascirev.2010.06.029

Paluska A, Veselý P, Modrý M, Waldhauser M, Rubáš D (2013) A project of new protected areas with ultramafic and associated dyke rocks in northern Bohemia. In: Büchner J, Rapprich V, Tietz O (eds) Abstract and excursion volume to the conference Basalt 2013, Görlitz, 24. 28. 4. 2013, pp. 240-241

Passey SR, Jolley DG (2009) A revised lithostratigraphic nomenclature for the Palaeogene Faroe Islands basalt group, NE Atlantic Ocean. Earth Env Sci T R So 99:127-158. https://doi.org/10.1017/ S1755691009008044

Petersen S (ed) (2015) CBD og Ramsar i småsamfund. Implementering af Biodiversitetskonventionen og Ramsarkonventionen i nordiske småsamfund - rapport fra workshop i Tórshavn den 11.-12. September 2014. Nordic Working Papers, Norden-Nordisk Ministerråd, Copenhagen, pp. 1-70

Phillips JC, Humphreys MCS, Daniels KA, Brown RJ, Witham F (2013) The formation of columnar joints produced by cooling in basalt at Staffa, Scotland. B Volcanol 75:715. https://doi.org/10.1007/ s00445-013-0715-4

Pokorný R, Krmíček L, Árting UE (2015) The first evidence of trace fossils and pseudo-fossils in the continental interlava volcaniclastic sediments on the Faroe Islands. Bull Geol Soc Den 63:45-57

Pralong J-P (2005) A method for assessing tourist potential and use of geomorphological sites. Géomorphologie 11:189-196

Ramsar Committee for Mykines (2016) Ramsar-ætlan fyri Mykines. Tilmæli um tiltøk at verja fugl, serliga sjófugl. (Translated: Ramsar plan for Mykines. Recommendations for initiatives to conserve bird life, especially sea birds). Available at http://www.us.fo/Default. aspx?ID $=14180$

Raška P, Cajz V (2016) Neovolcanic terrain of the České Středohoří Mountains. In: Pánek T, Hradecký J (eds) Landscapes and landforms of the Czech Republic. Springer Verlag, Berlin-Heidelberg, pp 139-152

Rasmussen J, Noe-Nygaard A (1969) Beskrivelse til geologisk kort over Færøerne i målestok 1:50000. Dan Geol Unders 24:1-370
Re G, White JDL, Ort MH (2015) Dikes, sills, and stress-regime evolution during emplacement of the Jagged Rocks complex, Hopi Buttes volcanic field, Navajo Nation, USA. J Volcanol Geotherm Res 295: 65-79. https://doi.org/10.1016/j.jvolgeores.2015.01.009

Reynard E, Coratza P (2007) Geomorphosites and geodiversity: a new domain of research. Geogr Helv 62:138-139. https://doi.org/10. 5194/gh-62-138-2007

Reynard E, Panizza M (2005) Geomorphosites: definition, assessment and mapping. Géomorphologie 11:177-180

Rudberg S (1984) Geological development and constructional forms. In: Embleton C (ed) Geomorphology of Europe. Macmillan Publishers, London, pp 49-53

Schofield N, Holford S, Millett J, Brown D, Jolley D, Passey SR, Muirhead D, Grove C, Magee C, Murray J, Hole M, Jackson CAL, Stevenson C (2017) Regional magma plumbing and emplacement mechanisms of the Faroe-Shetland Sill complex: implications for magma transport and petroleum systems within sedimentary basins. Basin Res 29:41-63. https://doi.org/10.1111/bre.12164

Slavíková L, Syrbe R-U, Slavík J, Berens A (2017) Local environmental NGO roles in biodiversity governance: a Czech-German comparison. GeoScape 11:1-15. https://doi.org/10.1515/geosc-2017-0001

Spry A (1962) The origin of columnar jointing, particularly in basalt flows. J Geol Soc Aust 8:191-216. https://doi.org/10.1080/ 14400956208527873

Statistics Faroe Islands (2016) Faroe Islands in figures 2016 (Hagstova Føroya 2016). Statistics Faroe Islands, Argir

Tefogoum GZ, Dongmo AK, Nkouathio DG, Merlin PW, Dedzo G (2014) Geomorphological features of the Manengouba volcano (Cameroon line): assets for potential geopark development. Geoheritage 6:225-239. https://doi.org/10.1007/s12371-014-0109-9

Ulrych J, Adamovič J, Krmíček L, Ackerman L, Balogh K (2014) Revision of Scheumann's classification of melilitic lamprophyres and related melilitic rocks in light of new analytical data. J Geosci 59:3-22. https://doi.org/10.3190/jgeosci.158

Ulrych J, Krmíček L, Teschner C, Řanda Z, Skála R, Jonášová Š, Fediuk F, Adamovič J, Pokorný R (2017) Tachylyte in Cenozoic basaltic lavas from the Czech Republic and Iceland: contrasting compositional trends. Mineral Petrol 111:761-775. https://doi.org/10.1007/ s00710-016-0483-x

Waagstein R, Guise P, Rex D (2002) K/Ar and ${ }^{39} \mathrm{Ar} /{ }^{40} \mathrm{Ar}$ whole-rock dating of zeolite facies metamorphosed flood basalts: the upper Paleocene basalts of the Faroe Islands, NE Atlantic. Geol Soc Lond Spec Publ 197:219-252. https://doi.org/10.1144/GSL.SP. 2002.197.01.09

\section{References to Legislative Documents}

Law Nr. 110 (1995) Løgtingslóg um náttúrufriðing, sum seinast broytt við løgtingslóg nr. 110 frá 29. juni 1995 http://logir.fo/Logtingslog/48fra-09-07-1970-um-natturufriding-sum-seinast-broytt-vidlogtingslog-nr-110-fra-29

Law Nr. 19 (2013) Løgtingslóg um broyting í løgtingslóg um býarskipanir og byggisamtyktir (Stytting av freist) http://logir.fo/ Logtingslog/19-fra-18-03-2013-um-broyting-i-logtingslog-umbyarskipanir-og-byggisamtyktir

Law Nr. 53 (1952) Lagtingslov nr. 53 af 27. november 1952 om plantager, som senest ændret ved lagtingslov nr. 110 af 29. juni $1995 \mathrm{http} / / /$ logir.fo/Lagtingslov/53-af-27-11-1952-om-plantagersom-senest-aendret-ved-lagtingslov-nr-110-af-29 